Jurnal Konstruksi Hukum | ISSN: XXXX | E-ISSN: XXXX Vol. 1, No. 1, September 2020 Hal. 227-231| Available online at https://www.ejournal.warmadewa.ac.id/index.php/jukonhum

DOI: https://doi.org/10.22225/jkh.1.1.2139.227-231

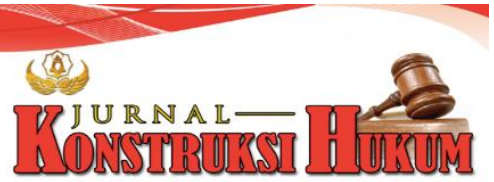

\title{
KEDUDUKAN ANAK SEBAGAI AHLI WARIS YANG BERALIH-ALIH AGAMA MENURUT HUKUM WARIS ADAT BALI
}

\author{
Gede Cahaya Putra Nugraha, I Made Suwitra, I Ketut Sukadana \\ Fakultas Hukum Universitas Warmadewa, Denpasar - Bali, Indonesia
}

\begin{abstract}
Abstrak
Kebebasan beragama yang dijamin oleh Negara dapat membawa konsekuensi pada adanya kemungkinan seseorang untuk beralih atau pindah agama dari agama satu ke agama yang lain. Menurut hukum waris adat Bali, beralih agama atau berpindah agama dapat berpengaruh terhadap kedudukan seorang anak sebagai ahli waris. Berdasarkan latar belakang tersebut, penelitian ini dilakukan dengan tujuan menggambarkan bagaimana kedudukan anak sebagai ahli waris yang beralih agama dari Agama Hindu dan bagaimana akibat hukum bagi anak sebagai ahli waris yang beralih agama dan kemudian kembali ke Agama Hindu. Metode penelitian yang digunakan adalah metode penelitian normatif dengan pendekatan Perundang-undangan yang menggunakan sumber bahan hukum primer, sekunder, dan tersier yang ditunjang dengan hasil wawancara yang kemudian dianalisa. Hasil penelitian menunjukkan bahwa kedudukan anak sebagai ahli waris yang beralih agama dari agama hindu secara hukum tidak lagi memiliki hak dan kewajiban terhadap orang tua, kerabat maupun masyarakat. Sedangkan akibat hukum bagi anak sebagai ahli waris yang beralih agama adalah hilangnya hak anak tersebut karena sudah tidak bisa memikul segala kewajiban yang akan diteruskan oleh orang tuanya dan sudah dianggap durhaka kepada orang tua dan leluhurnya. Namun, dengan kembalinya anak tersebut menjadi Agama Hindu, maka segala hak dan kewajiban yang sebelumnya ditinggalkan dapat diterimanya kembali dengan syarat-syarat tertentu yang disepakati oleh keluarga yang bersangkutan.
\end{abstract}

Kata Kunci: Ahli waris; Beralih-alih agama; Hukum waris adat bali

\begin{abstract}
The freedom of religion guaranteed by the State can lead to the possibility of a person converting or changing religions from one religion to another. According to Balinese traditional inheritance law, changing religions can affect a child as an heir. Based on this background, this research was conducted with the aims of describing the position of a child as heir who changed religion from Hinduism and outlining the legal consequences for a child as the heir who converted and then returned to Hinduism. The research method used was a normative research method with a statutory approach that used primary, secondary, and tertiary legal materials which were supported by the results of interviews and then analyzed. The results showed that the rank of children as heirs who converted from Hinduism legally no longer had rights and obligations towards their parents, relatives and society. Meanwhile, the legal consequence for children as heirs who change religions is the loss of the child's rights because they are unable to carry all the obligations that will be passed on by their parents and are considered disobedient to their parents and ancestors. However, with the return of the child to Hinduism, all rights and obligations that were previously abandoned can be accepted back with certain conditions agreed upon by the family concerned.
\end{abstract}

Keywords: Inheritance; Switching religion; Balinese traditional inheritance law

\section{PENDAHULUAN}

Keberadaan masyarakat di daerah selalu dikaitkan dengan hukum adat karena mereka harus mematuhi hukum adat yang berlaku. Keberadaan hukum adat tercermin dari kebiasaan-kebiasaan masyarkat di lingkungan sekitar. Hukum adat mempunyai sifat tradisional yang terlihat dari kebiasaan yang hidup di dalamnya. Hukum adat dapat berkembang dan mengikuti kemajuan masyarakat dan agama dan kebudayaan dapat memepengaruhi hukum adat (Manarisip, 2012; Susylawati, 2009).

Kehidupan keagamaan di negara Indonesia telah diatur dalam Pasal 29 Undang-undang Dasar Negara Republik Indonesia Tahun 1945 yang berbunyi:

1. Negara berdasarkan atas Ketuhanan Yang Maha Esa. 
2. Negara menjamin kemerdekaan tiap-tiap penduduk untuk memeluk agamanya masing-masing dan untuk beribadat menurut agama dan kepercayaannya itu.

Menurut Ketetapan No. II tahun 1978, kebebasan agama adalah merupakan salah satu hak yang paling asasi di antara hak asasi manusia karena kebebasan beragama itu langsung bersumber kepada martabat manusia sebagai makhluk ciptaan Tuhan. Hak kebebasan beragama bukan pemberian negara atau pemberian golongan (Pudja, 1982; Sodikin, 2013).

Salah satu akibat adanya kebebasan beragama adalah seseorang bisa beralih agama ke agama lain selain yang dianut sebelumnya sesuai dengan kepercayaan dan keyakinannya (Jufri, 2017; Putri, 2011; Syafi'ie, 2011). Oleh karena itu, dapat dikatakan bahwa Indonesia tidak melarang seseorang untuk beralih agama. Menurut hukum adat Bali, seseorang yang beralih agama akan mempengaruhi kedudukan sebagai ahli waris dalam sistem pewarisan.

Peralihan agama sesuai dengan hukum adat Bali mempunyai pengaruh pada kedudukan ahli waris (Prabowo, Windia, \& Wirawan, 2018). Hukum adat waris di Bali mengatur tentang peralihan agama yang merupakan proses penurunan kewajiban dan hak suatu generasi ke generasi selanjuntya, dengan kata lain, kewajiban yang diikuti dengan pelekatan hak. Adapun kewajban yang dimaksud berupa kewajiban untuk berhak dan kewajiban bermasyarakat di adat. Selain kewajiban, hak yang dimaksud adalah hak untuk menikmati harta benda yang diwariskan oleh pewaris.

Apabila peralihan agama dikaitkan dengan hukum adat warisan terutama harta warisan, terdapat perbedaan pendapat oleh para ahli hukum. Menurut Hadikusuma (2003), warisan yang diperoleh seorang ahli waris tidak akan berkurang meskipun ahli waris berpindah agama.Hal ini menyebabkan terjadinya pertentangan di antara ahli hukum di mana yang satu menyatakan bahwa ahli waris yang berpindah agama diberikan haknya dan pendapat lain memberikan pendapat bahwa ahli waris yang beralih agama tidak mendapatkan hak atas warisan dari pewarisnya.

Berdasarkan latar belakang masalah tersebut di atas, penelitian ini dilakukan dengan tujuan mendeskripsikan bagaimana kedudukan anak sebagai ahli waris yang beralih agama dari agama Hindu dan bagaimana akibat hukum anak bagi anak sebagai ahli waris yang beralih agama dan kemudian kembali ke agama Hindu.

\section{METODE PENELITIAN}

Penelitian ini didesain dengan menggunakan metode penelitian hukum normatif. Pendekatan masalah yang dipergunakan dalam penelitian ini adalah pendekatan Perundang-Undangan (statute approach), dilakukan dengan menelaah semua undang-undang dan regulasi yang bersangkut paut dengan isu hukum yang sedang ditangani atau peraturan-peraturan. Bahan hukum primer dikumpulkan dengan teknik dokumentasi dan bahan hukum sekunder dikumpulkan dengan teknik pencatatan dari bahanbahan hukum kepustakaan yang berhubungan dengan hak waris bagi anak yang beralih-alih agama. Analisis bahan hukum menggunakan teknik interpretasi sistematis yang selanjutnya dituangkan secara deskriptif dalam bentuk jurnal.

\section{HASIL DAN PEMBAHASAN}

\section{Kedudukan Anak sebagai Ahli Waris yang Beralih Agama dari Agama Hindu}

Seorang ahli waris dibatalkan haknya untuk mewaris harta warisan orang tuanya. Disamping itu seorang ahli waris dapat juga kehilangan hak mewarisnya, apabila ahli waris tersebut beralih agama dari agama Hindu ke agama lainnya, seperti apa yang dikemukakan oleh I Gde Pudja, Meninggalkan agama leluhur dianggap juga sebagai sebab lenyapnya kedudukan mereka sebagai ahli waris. Kejadian ini pun dapat dianggap sebagai kejadian durhaka terhadap leluhur karena sebagai akibat dari meninggalkan agama yang dianut oleh leluhurnya, jelas mereka tidak akan dapat melakukan kewajiban-kewajiban sebagai kewajiban seorang anak (putra) terhadap leluhurnya (Pudja, 1977).

Biasanya yang beralih agama itu bisa anak laki-laki atau anak perempuan. Untuk menanggulangi permasalahan yang timbul apabila terjadi sengketa di antara warga desa, tetua-tetua adat membuat suatu peraturan tertulis dan sah berdasarkan musyawarah. Peraturan itu bernama awigawig yang lazim dimiliki oleh setiap desa adat di Bali, termasuk pula pada Desa Adat Panjer. Aturan ini ditaati dan diakui karena mereka harus menerimanya agar tercapai ketentuan dalam masyarakat. Jadi, mereka selaku warga Desa Adat Panjer menganggap aturan itu sebagai peraturan hukum, dan bagi yang melanggarnya dapat dikenai sanksi. Dengan demikian ahli waris yang beralih agama di Desa Adat Panjer tidak melaksanakan kewajiban-kewajiban sebagaimana kewajiban ahli waris yang 
tetap beragama Hindu, dan mereka sudah tidak ada lagi mempunyai hubungan dengan Desa Adatnya yang berkaitan erat dengan masyarakat sosialnya.

Pada umumnya semua harta warisan diperuntukkan bagi semua ahli waris sebagai harta benda peninggalan pewaris kepada semua ahli warisnya. Namun tidak demikian adanya di Bali yang mengenal adanya pembatasan-pembatasan tertentu dalam pembagian harta warisannya, di mana dikenal adanya harta benda yang tidak boleh dibagi-bagi, seperti: harta pusaka yang mempunyai nilai magis - religius, alat upakara di sanggah dadia, pemerajan atau sanggah, dan Keris pengentas dan senjata - senjata kepunyaan keluarga. Tanah bukti sanggah dadia, pemerajan, dan laba pura pada hakekatnya ditujukan untuk kepentingan pemeliharaan.

Berdasarkan hasil wawancara dengan A.A. Ketut Oka Adnyana sebagai Bendesa Adat Desa Adat Panjer mengatakan bahwa jika seorang anak beralih agama dari Agama Hindu menjadi agama lain, maka hubungan anak tersebut secara hukum adat sudah terputus dengan orang tuanya. Kedudukan hak dan kewajiban anak tersebut terhadap orang tuanya yang seharusnya dilaksanakan pada saat masih beragama Hindu sudah tidak ada lagi. Hubungan antara anak dengan orang tuanya yang masih tersisa adalah hubungan darah karena tidak dapat dipungkiri bahwa anak tersebut dilahirkan oleh orang tuanya (wawancara dengan A.A Ketut Oka Adnyana di Panjer pada tanggal 27 Juli 2019).

Berdasarkan hasil wawancara yang dilakukan dengan A.A Ketut Oka Adnyana, SST, M.Si sebagai Bendesa Desa Adat Panjer menyatakan, seseorang yang beralih agama dari Agama Hindu dikatakan sudah tidak lagi termasuk dalam masyarakat adat. Seseorang yang beralih agama sudah tidak memiliki hak dan kewajiban terhadap Desa Adat Panjer. Seseorang yang sudah beralih agama tidak lagi tinggal bersama dengan orang tuanya yang masih beragama Hindu, namun masih diperbolehkan tinggal di Desa Adat Panjer dengan status sebagai Tamiyu. Jika ada kematian, seseorang yang beralih agama tersebut tidak lagi mendapatkan bantuan dari masyarakat adat dan juga orang yang beralih agama tersebut tidak diperkenankan untuk menggunakan fasilitas kuburan adat (Wawancara dengan A.A Ketut Oka Adnyana di Panjer pada tanggal 27 Juli 2019).

Oleh karena itu, seorang ahli waris yang beralih agama tidak diperbolehkan menguburkan jenazahnya pada kuburan adat melainkan hanya boleh dikuburkan pada pemakaman umum. Hal tersebut berarti bahwa seseorang yang beralih agama dinyatakan lepas hubungan dengan desa adat dan masyarakatnya yang beragama Hindu.

\section{Akibat Hukum bagi Anak sebagai Ahli Waris yang Beralih Agama}

Berdasarkan keterangan yang diberikan oleh A.A Ketut Oka Adnyana sebagai Bendesa Desa Adat Panjer bahwa bilamana seorang anak yang merupakan ahli waris telah berpindah agama dari Agama Hindu ke agama lain, maka hubungan antara pewaris dengan ahli waris dinyatakan sudah terputus karena ahli waris sudah tidak dapat lagi melaksanakan kewajiban-kewajibannya. Ahli waris tidak berhak lagi menuntut harta warisan kepada pewaris. Namun jika keadaan ekonomi pewaris berkecukupan dan bisa dibilang kaya karena memiliki harta benda yang banyak, maka dengan penuh kesadaran pewaris diperbolehkan memberikan sedikit harta benda pemberian kepada ahli waris yang disebut jiwa dana karena pembagian warisan bersifat kekeluargaan di mana orang lain tidak boleh ikut campur dalam hal pembagian warisan dan dalam hal ini Adat hanya menjadi saksi dalam proses tersebut (wawancara dengan A.A Ketut Oka Adnyana pada tanggal 27 Juli 2019).

Kembalinya seseorang ke agama Hindu setelah sebelumnya ditinggalkan terjadi karena adanya fenomena niskala yakni adanya bisikan leluhur, alasan hubungan perkawinan, karena adanya ketidakpuasan dalam diri sendiri, adanya hubungan kekeluargaan dan kesadaran diri yang ingin memperbaiki citra diri ke arah yang positif (Premana, 2016:12-14). Seseorang yang berkeinginan untuk kembali memeluk agama Hindu harus memenuhi syarat-syarat yang sesuai dengan hukum Hindu, yaitu harus melaksanakan upacara Sudhi Wadani. Sudhi Wadani berasal dari kata sudhi yang berarti penyucian, persembahan, upacara pembersihan/ penyucian dan wadani yang berarti perkataan. Jadi, sudhi wadani adalah upacara dalam Hindu sebagai pengukuhan atau pengesahan ucapan atau janji seseorang yang secara tulus ikhlas untuk menyatakan menganut agama Hindu (Departemen Agama, 1998). Upacara ini harus dilakukan atas keinginan hati nurani sendiri tanpa ada paksaan dari pihak manapun. Setelah melakukan upacara sudhi wadani, seorang anak yang sebelumnya beralih agama dari agama Hindu sudah dinyatakan sah memeluk agama Hindu lagi. 
Berdasarkan hasil wawancara dengan A.A Ketut Oka Adnyana sebagai Bendesa Desa Adat Panjer mengatakan bahwa seorang anak yang sebelumnya beralih agama dan kini kembali memeluk agama Hindu wajib melaksanakan upacara sudhi wadani sebagai syarat sah untuk masuk ke agama Hindu. Dengan kembali memeluk agama Hindu, maka dia berhak mendapatkan kembali haknya atas harta warisan orang tuanya yang sebelumnya ditinggalkan. Namun hal ini juga harus mendapat persetujuan dari saudaranya yang tidak beralih agama (wawancara dengan A.A Ketut Oka Adnyana di Panjer pada tanggal 27 Juli 2019).

Dengan diterimanya lagi hak-haknya yang sebelumnya telah hilang sebagai akibat dari beralihnya agama yang dilakukannya, maka kewajiban- kewajibannya terhadap orang tua maupun kerabatnya harus kembali dilaksanakan. Sebagai perwujudan rasa baktinya kepada leluhurnya, maka anak tersebut wajib untuk kembali melaksanakan upacara-upacara keagamaan dan pemeliharaan di pemerajan atau sanggah-nya. Keputusan ini harus berdasarkan hasil musyawarah dalam keluarga agar tidak terjadinya pertikaian antar saudara karena adanya perbedaan rasa tanggung jawab pada saat beralihnya agama dari saudaranya.

Adapun keterangan tambahan yang diberikan oleh A.A Ketut Oka Adnyana adalah apabila seseorang yang sebelumnya beralih agama dari agama Hindu berkeinginan kembali masuk dan memeluk agama Hindu seperti agama yang dianut orang tuanya, maka tidak ada yang boleh melarang orang tersebut untuk kembali ke agama leluhurnya. Selain hak dan kewajibannya sebagai seorang ahli waris terhadap orang tuanya, dia berhak untuk menerima kembali hak-haknya di desa adat untuk menggunakan fasilitas adat seperti kuburan adat dan kewajibannya sebagai penerus orang tuanya di desa adat seperti gotong royong maupun melaksanakan upacara keagaaman di Pura Khayangan Tiga wajib dilaksankannya lagi (wawancara pada tanggal 27 Juli 2019).

Berdasarkan hal tersebut di atas, dapat dikatakan bahwa anak yang sebelumnya beralih agama jika kembali memeluk agama Hindu yang merupakan agama leluhurnya, anak tersebut kembali menjadi ahli waris. Dengan kembali menjadi ahli waris, anak tersebut berhak atas warisan orang tuanya serta mendapatkan pengakuan dari desa adat dan berkewajiban menjalankan segala kewajibankewajiban dan tanggung jawab yang dulu ditinggalkannya karena beralih agama sebelumnya.

\section{SIMPULAN DAN SARAN}

\section{Simpulan}

Berdasarkan uraian di atas, ada beberapa simpulan yang dapat dibuat, yaitu: pertama, kedudukan anak sebagai ahli waris yang beralih agama dari agama Hindu secara hukum sudah tidak ada lagi dan sudah tidak lagi memiliki hak dan kewajiban terhadap orang tua, kerabat maupun masyarakat karena tidak dapat lagi melaksanakan kewajiban terutama kewajiban yang bersifat keagamaan dan adat. Dengan terputusnya hubungan kekeluargaan dengan orang tuanya, maka seorang anak yang beralih agama tidak berhak lagi atas harta warisan orang tuanya. Namun orang tua masih bisa memberikan berupa bekal kepada anaknya yang disebut jiwa dana sebagai rasa belas kasih dan sayang orang tua kepada anaknya. Kedua, akibat hukum bagi anak sebagai ahli waris yang beralih agama adalah anak tersebut kehilangan hak menjadi ahli waris karena sudah tidak bisa memikul segala kewajiban yang akan diteruskan oleh orang tuanya dan hal ini sudah dianggap duhaka terhadap orang tua maupun leluhurnya. Namun dengan kembalinya anak yang sebelumnya beralih agama ke agama Hindu, maka segala hak dan kewajiban yang sebelumnya ditinggalkan akan kembali dengan diterimanya dengan syarat melaksanakan upacara sudhi wadani dan bersedia kembali melaksanakan segala kewajibannya sebagai seorang ahli waris.

\section{Saran}

Sesuai dengan simpulan tersebut diatas, ada beberapa saran yang perlu disampaikan kepada beberapa pihak, yaitu: pertama, bagi seorang anak yang merupakan seorang ahli waris diharapkan untuk memikirkan matang-matang sebelum memiliki keinginan untuk beralih agama agar tidak terjadi putusnya hubungan dengan orang tuanya, keluarga, leluhur, maupun masyarakat adatnya. Hal ini bertujuan untuk menghindari terjadinya konflik antar keluarga yang berhubungan dengan pewarisan karena adanya perbedaan agama dari para ahli waris. Kedua, diharapkan peran Prajuru Adat ditingkatkan dalam penyadaran kepada masyarakat adatnya yang sudah terlanjur beralih agama dari agama Hindu serta meminimalisir beban yang diberikan kepada masyarakat adat terkait kegiatan upacara keagamaan agar masyarakat nyaman sebagai masyarakat adat. 


\section{DAFTAR PUSTAKA}

Departemen Agama. (1998). Tuntunan Pelaksanaan Upacara Sudhi Wadani. Jakarta: Direktorat Jenderal Bimbingan Masyarakat Hindu dan Budha.

Hadikusuma, H. (2003). Pengantar Hukum Adat Indonesia. Bandung: CV Mandar Maju.

Jufri, M. (2017). Perbandingan Pengaturan Hak Kebebasan Beragama antara Indonesia dengan Majapahit. Jurnal Konstitusi, 14(2), 396-417.

Manarisip, M. (2012). Eksistensi Pidana Adat dalam Hukum Nasional. Lex Crimen, 1(4), 39.

Prabowo, A., Windia, I. W., \& Wirawan, I. K. (2018). Peralihan Status Kepemilikan Tanah Warisan Menjadi Tanah Pelaba Pura dalam Masyarakat Hukum Adat Bali (Studi Kasus di Desa Adat Canggu). Jurnal Ilmiah Prodi Magister Kenotariatan, 296-304.

Premana, I. K. S. (2016). Rekonversi Beragama di Kecamatan Kuta Utara, Kabupaten Badung. Universitas Udayana.

Pudja, I. G. (1977). Hukum Kewarisan Hindu Yang Diresepir ke dalam Hukum Adat di Bali Dan Lombok. Jakarta: CV. Junasco.

Pudja, I. G. (1982). Pedoman Penghayatan dan Pengamalan Pancasila dan Ajaran Hindu Dharma (IV). Jakarta: Direktorat Jendral Bimbingan Masyarakat Hindu dan Budha Departemen Agama RI.

Putri, N. S. (2011). Pelaksanaan Kebebasan Beragama Di Indonesia (External Freedom) Dihubungkan Ijin Pembangunan Rumah Ibadah. Jurnal Dinamika Hukum, 11(2), 230-242.

Sodikin. (2013). Hukum dan Hak Kebebasan Beragama. Jurnal Cita Hukum, 1(2), 175-186.

Susylawati, E. (2009). Eksistensi Hukum Adat dalam Sistem Hukum di Indonesia. Al-Ihkam: Jurnal Hukum Dan Pranata Sosial, 4(1), 124-140.

Syafi'ie, M. (2011). Ambiguitas Hak Kebebasan Beragama di Indonesia dan Posisinya Pasca Putusan Mahkamah Konstitusi. Jurnal Konstitusi, 8(5), 675-706. 